\title{
Bladder Hepatoid Adenocarcinoma
}

National Cancer Institute

\section{Source}

National Cancer Institute. Bladder Hepatoid Adenocarcinoma. NCI Thesaurus. Code C39838.

A rare variant of bladder adenocarcinoma. It is characterized by the presence of a mixture of polygonal hepatoid cells and glandular adenocarcinoma cells. 